\title{
OS SENTIDOS DE PRISÃO NA POESIA DE ADELIA STEDILE DE MATOS
}

\section{THE SENSES OF PRISON IN THE POETRY OF ADELIA STEDILE DE MATOS}

Anna Clara de Oliveira Carling'

Cristinne Leus Tomé2

\begin{abstract}
RESUMO: Neste trabalho seráo analisados os sentidos da mulher em dois poemas do livro Sobre mulheres e vidas, publicado em 2014, de autoria da poetisa sinopense Adelia Stedile de Matos. A análise será desenvolvida sob os moldes teórico-analíticos da Análise do Discurso de linha francesa, tendo como norteadores os conceitos de Condiçôes de Produçăo, Formaçôes Imaginárias, Discursivas e Ideológicas, Interdiscurso e Sujeito. Além disso, será apresentada uma pesquisa biográfica da poetisa, como forma de contribuir com as condiçôes de produçâo dos discursos. Esta biografia foi construída a partir de entrevistas com a própria poetisa e com professores da Universidade do Estado de Mato Grosso (UNEMAT), local onde ela estudou e trabalhou. De maneira específica buscou-se compreender como se formam as imagens do sujeito-mulher na poesia de Adelia. Conclui-se que as mulheres de Adelia săo constituídas por formaçōes ideológicas que colocam esse sujeito em prisóes formadas pelas relaçóes de poder entre homens e mulheres, relaçóes estas legitimadas pela sociedade.
\end{abstract}

PALAVRAS-CHAVE: Mulher. Adelia Stedile de Matos. Análise do Discurso.

ABSTRACT: This Project presents the biographical research on Adelia Stedile de Matos, a notable poet from Sinop, Mato Grosso, it also analyses all the possible meanings related to women in her book, Sobre mulheres e vidas, published in 2014. The analysis follows the principles of the French Discourse Analysis, taking into account the concepts of conditions of production, imaginary, discursive and ideological formation, interdiscourse, and positioning theory. The author's biography was put together by a number of interviews given to the professors of Universidade do Estado de Mato Grosso, institution where Stedile studied and has worked for years. Specifically, the purpose of this paper is to comprehend how images of women as a subject are constructed in Adelia's work. Therefore, we conclude that Adelia's women are composed by ideological

1 Mestranda em Letras pela Universidade Estadual de Maringá (UEM). annaclaracarling@gmail.com

2 Doutora em Educaçăo pela Universidade Federal do Rio Grande do Sul (UFRGS). Professora do Curso de Pedagogia e do Mestrado Acadêmico do Curso de Letras do Câmpus de Sinop, Faculdade de Educaçāo e Linguagem (FAEL) da Universidade do Estado de Mato Grosso (UNEMAT). Líder do Grupo de Pesquisa Educaçăo e Estudos de Linguagem (GEdEL), Coordenadora do Projeto de Pesquisa Leituras Urbanas e suas materialidades discursivas socioambientais no Norte do Mato Grosso. cristinne.tome@unemat.br 
formations that put them in prisons built by power relations between men and women, relations which are legitimated by society.

KEYWORDS: Woman. Adelia Stedile de Matos. Discourse analysis.

\section{INTRODUÇÃO}

Este trabalho tem por objetivo analisar de que forma a representaçâo da mulher se materializa na poesia de Adelia Stedile de Matos, tomando como base a teoria da Análise do Discurso de linha francesa como metodologia analítica. Como năo há registrado nenhum estudo sobre a autora, constituir-se-á uma biografia que contribui para as Condiçôes de Produçăo deste trabalho. Para tanto, foram realizadas entrevistas com a autora, e analisados dois de seus poemas presentes na obra Sobre mulheres e vidas, publicada em 2014.

Observando o panorama sócio histórico da sociedade, é possível perceber o caráter de dominância do homem em relaçâo à mulher. Materializam-se os preconceitos, a falta de direitos, a pouca autonomia, a violência (velada ou explícita), a falta de liberdade e opressôes sofridas pela mulher por imposiçôes de uma sociedade que dava voz unicamente ao homem. Apesar de a condiçấo social da mulher ter sido expressivamente equilibrada em relaçâo à figura masculina nos últimos tempos, ainda existem muitos pontos de desarmonia. Transformando essas questôes em trabalho de interpretaçăo, intencionou-se, nesta pesquisa, contribuir para esse importante debate, e, ao mesmo tempo, destacar a emergente cultura matogrossense.

O trabalho foi dividido da seguinte forma: primeiramente será apresentada uma breve biografia de Adelia Stedile de Matos, cuja figura tem grande importância para a sociedade sinopense. Esta parte da pesquisa teve cunho na história oral, que serviu de apoio para um melhor tratamento dos dados coletados.

Em seguida, foi desenvolvido um estudo sobre a teoria da Análise do Discurso, onde foram explicitados os conceitos que servirâo de base para as análises, sendo estes as Condiçôes de Produçâo, as Formaçōes Imaginárias, Discursivas e Ideológicas, o Interdiscurso e o Sujeito. Portanto, amparados na teoria da Análise do Discurso, buscou-se analisar de que modo os sentidos do Discurso da/sobre a mulher sâo evidenciados na poesia de Adelia Stedile de Matos, intencionando contribuir com as discussôes a respeito da disparidade entre homens e mulheres em sociedade.

O corpus de análise é constituído por 2 poemas de Adelia, os quais serăo a ponte para o acesso aos discursos da/sobre a mulher materializados pela autora. Daremos enfoque às prisōes da mulher, que sâo os sentidos mais fortemente percebidos no delinear das análises.

Nas consideraçóes finais sâo discutidas as conclusóes que as análises possibilitaram, que apontam que a constituiçâo do sujeito-mulher é guiada pela memória discursiva que se tem desse sujeito e, por este motivo, os sentidos que se constituem sobre a mulher sâo permeados de aprisionamentos. 


\section{ADELIA STEDILE DE MATOS: UMA BIOGRAFIA}

A partir de entrevistas semiestruturadas, tanto com Adelia quanto com professores da Universidade do Estado de Mato Grosso - câmpus Sinop, as seguintes informaçóes foram colhidas.

Adelia Stedile de Matos, filha de Lodovino Pedro Stedile e Emma Simionatto, nasceu no dia 01 de maio de 1948 no distrito de Charrua, interior do município de Getúlio Vargas, no Rio Grande do Sul, e aos 3 anos mudou-se para o município de Cidade Gaúcha, no noroeste do Paraná, onde viveu a infância inteira em uma zona rural. Filha de agricultores, ela conta que a infância foi muito difícil. Estudava, na década de 50, em uma escola multisseriada chamada Escola Municipal Borges de Medeiros, localizada no interior da cidade. Mas apesar das dificuldades, Adelia narra que sua professora daquele período, Suely Oliveira de Lucena, foi fundamental para seu desenvolvimento.

Minha professora de $1^{\mathrm{a}}$ a $4^{\mathrm{a}}$ série multisseriada, era uma professora fora de época. Ela seria uma professora que as escolas hoje procuram para trabalhar. Aquela professora envolvida, aquela professora esforçada, comprometida, que vai buscar recursos, que vai buscar elementos, que vai buscar motivaçăo e trabalha a realidade da criança. Para mim ela foi uma base muito grande, ela fez uma revoluçăo na minha vida. (MATOS, 2018a).

A família era muito grande e um problema de pele assolava a ela e a outros três irmáos, dentre um total de 11, sendo eles, por ordem de nascimento: Francisco Pedro Stedile, Adelia Stedile, Otília Stedile, Lorena Stedile, Euclides Miguel Stedile, Terezinha Stedile, Alerina Stedile, Belmiro Luiz Stedile, Marisa Stedile, Eliane Stedile e Armindo Antonio Stedile. A doença genética de nome Xeroderma Pigmentoso é caracterizada pela grande sensibilidade à luz solar, o que, na família de Adelia, ocasionava muito cuidado para que os portadores da doença năo se expusessem longamente ao sol.

Aproximadamente no ano de 1963 aconteceu uma forte geada, seguida por uma seca que ocasionou incêndio, destruindo toda a plantaçăo de café e capim das terras de sua família. Essa sequência de infortúnios obrigou seu pai, Lodovino, a vender as terras de Cidade Gaúcha e se mudar com a família para a cidade de Toledo - PR, lugar onde ela e algumas de suas irmăs estudaram, sob muitas dificuldades, na Escola Normal Colegial Imaculado Coraçâo de Maria, um colégio particular católico. Lá sofreu muito preconceito por vir de uma família de baixa renda e estar num ambiente dominado por pessoas de grande posse monetária. Além disso, percebia que seu problema de pele agravava as situaçōes de preconceito.

Tinham várias situaçóes que a gente passava porque éramos pobres. Entăo as principais perseguiçóes eram pelo jeito de vestir, porque a gente era pobre e envergonhava o colégio. Nunca ninguém jogou na cara da gente, mas năo precisava jogar. Falar, a gente falava errado. $\mathrm{O}$ sotaque, o linguajar da gente mostrava que a gente era caipira, do mato. (MATOS, 2018b).

Adelia conta que sua família sempre a incentivou a estudar. Além de sua avó, diversas tias e irmás também se dedicaram à carreira docente. Sua professora do ensino fundamental também foi uma importante figura para que o interesse por ser 
professora despertasse. Já no começo de seu ensino médio, iniciou sua carreira como professora, ministrando aulas para uma turma de primeiro ano do ensino fundamental. Além disso, nessa mesma época dava aula para turmas do Movimento Brasileiro de Alfabetizaçăo (MOBRAL), um programa que visava a alfabetizaçăo de adultos. Esse programa funcionou dos anos 1970 a 1985, quando, com a restituiçăo da República, foi extinto (OLIVEIRA; SOUZA, 2012). Por ter iniciado a profissăo como docente tâo cedo, sua experiência sobre o fazer pedagógico ainda năo era vasta. "Faz mal lembrar a minha inexperiência, a minha falta de conhecimento. Eu ter ido para a sala de aula sem a mínima fundamentaçăo teórica, sem estágio, sem nada..." (MATOS, 2018a).

Contudo, seu trabalho continuou a se desenvolver, até que em 1969 passou no concurso de professores de Toledo - PR. Apesar da conquista, a cidade era muito conservadora, entăo a chegada de novos professores à escola a qual Adelia foi direcionada abalou as estruturas que se mantinham no ambiente escolar. Por isso, foi coagida a desistir de sua vaga no concurso. Foi com o apoio de seu pai que, apesar da pressấo de seus colegas, ela se manteve firme na ocupaçăo de sua vaga. No entanto, como o Brasil se encontrava no período de Regime Militar, - movimento que teve início em 1964 com um golpe de Estado e teve seu término em 1985 com a restituiçăo da República, por meio de manifestaçóes da populaçáo, sendo um período de bastante repressâo, onde qualquer expressâo que fosse considerada subversiva era controlada (TODA MATERIA, 2018) - seu trabalho nāo foi fácil.

Entretanto, apesar das dificuldades, Adelia se orgulha de seu trabalho como professora. Considera que aprendeu muito sobre educaçăo ao longo do tempo, adquiriu experiências importantes, mesmo em ambientes que nâo facilitavam o trabalho de maneira proveitosa. "As escolas que eu trabalhei, a grande maioria eram públicas. Todas elas muito mais me ensinaram do que eu ensinei, porque para mim foi um aprendizado e a vida está sendo um aprendizado constante" (MATOS, 2018a).

Nesse período, Adelia se casou em Toledo - PR, no dia 24 de novembro de 1973 e, ao lado de seu marido Osvaldo Henrique de Matos, teve três filhos: Renato Stedile de Matos, Liliane Stedile de Matos e Renata Stedile de Matos.

No decorrer de sua vida profissional, Adelia chegou a ser diretora de uma escola em Toledo, passou por várias outras unidades escolares como professora, até que, após 1 ano sem trabalhar por năo ter condiçóes de se locomover à escola que foi designada, Adelia migrou com seu esposo e filhos para Sinop - Mato Grosso, em 1986.

Assim que chegou em Sinop, Adelia trabalhou como professora em algumas escolas públicas e privadas da cidade, até que em 1990, ingressou na primeira turma do Curso de Pedagogia da Fundaçấo de Ensino Superior de Mato Grosso (FESMAT), que, posteriormente, viria a se tornar a Universidade do Estado de Mato Grosso (UNEMAT). Como a Universidade ainda estava em processo de implementaçấo, a continuidade da instituiçâo em Sinop ainda náo era certa, logo, eram necessárias intervençôes recorrentes como forma de informar a sociedade da importância da implantaçăo e permanência da Universidade no município. Por conta disso, Adelia ficou muito tempo fora de sala, em reuniôes do Colegiado do Curso de Pedagogia, por ser sempre ativa nas questôes referentes à UNEMAT. Em entrevista, o Professor Doutor Aumeri Carlos Bampi e o Professor Doutor Fiorelo Picoli relembraram a atuaçăo de Adelia na UNEMAT. 
Ela foi uma pessoa que contribuiu decisivamente para a consolidaçăo, também, do curso de Pedagogia. Primeiro como aluna, organizando também o Diretório Estudantil que era uma questăo importante, porque os alunos começaram também a mostrar suas necessidades, ou seja, o que eles pretendiam e o que necessitavam para ter uma formaçăo adequada. (BAMPI, 2018).

A Adelia é tida como uma das maiores lutadoras da Universidade. Desde a implementaçăo até a sua permanência [...], tendo em vista que a UNEMAT era para ser privatizada aqui, e a Adelia com o grupo da Pedagogia fez de tudo para năo deixar acontecer, ela enquanto acadêmica. Entấo, a Adelia tem uma importância muito grande para UNEMAT. (PICOLI, 2018).

A partir dos relatos dos professores que acompanharam o processo de implantaçáo da UNEMAT, bem como a formaçăo de Adelia enquanto acadêmica, podemos imaginar as adversidades existentes naquele período, da mesma forma que fica evidente a relevância da autora para a referida Instituiçăo, visto que Adelia lutou pela UNEMAT em seus períodos mais vulneráveis.

Após finalizar sua formaçăo, Adelia regressou com a família para Toledo, em 1996, pois as circunstâncias em Sinop nâo eram as melhores. Ela havia pedido exoneraçáo de seu cargo como professora pois o salário era muito baixo e năo conseguia conciliar os estudos com o trabalho na escola e os afazeres doméstico. Entretanto, em Toledo os planos năo seguiram como o imaginado, entăo, depois de 9 meses Adelia retornou novamente a Sinop, em 1996. Ela voltou a trabalhar como professora na escola Nossa Senhora da Glória e, após cerca de dois anos, em 1998, passou no concurso para professores da UNEMAT, tornando-se, assim, professora efetiva da Instituiçăo.

$\mathrm{Na}$ Universidade ministrou diversas disciplinas, principalmente de Estágio Supervisionado, que é a disciplina que mais gostava. Além disso, foi Chefe de Departamento de Pedagogia, tomando frente de um dos períodos mais difíceis do Departamento, pois era a fase em que o Curso estava sendo avaliado para a definiçâo do reconhecimento ou năo, como curso institucionalizado.

Seu trabalho continuou na Universidade, intercalando seus esforços ora como professora, ora administrando cargos de coordenaçăo, tanto no câmpus de Sinop como em outras unidades, como Juara - MT, onde, em 2001, coordenou o núcleo em seu período de implantaçấo. O Professor Doutor Aumeri Carlos Bampi, que foi quem a convidou para o desafio da abertura do câmpus de Juara, relembrou essa fase:

É uma pessoa que tem que ser reconhecida e admirada no seu processo de configuraçăo histórica também, pelas dificuldades que passou, mas nunca se rendeu às condiçôes dadas, buscando superar desafios, seja aqui nas condiçóes que às vezes na sala de Pedagogia elas tinham que sentar nas cadeiras de pré-escola. [...] quer seja quando foi para Juara e buscar toda a instalaçấo do núcleo, que viria a ser um câmpus posteriormente. E isso tinha que abrir măo, às vezes, da sua própria convivência familiar... Por estar há $300 \mathrm{~km}$ de distância, e isso năo é uma questăo fácil... Se deslocar para Cáceres, para outros locais nos cursos que tínhamos no interior... Isso em meio a muitas dificuldades. Estradas intrafegáveis, dificuldades de locomoçăo, dificuldades de recurso... tudo isso eu creio que ela conseguiu superar, náo no sentido de conseguir trazer todas as condiçōes, mas superar e dizer "nós podemos 
fazer uma educaçăo bem feita", năo independente das condiçôes, mas buscando condiçōes melhores e vendo com o que é possível trabalhar. (BAMPI, 2018).

Entre idas e vindas de Juara a Sinop, Adelia retornou ao câmpus de Sinop onde se manteve até sua aposentadoria, em 2011. Depois de aposentada, a autora reuniu poemas sob a temática da mulher e, em 2014 publicou o livro Sobre mulheres e vidas, obra que é o interesse desta pesquisa, que relata em vinte e cinco poemas, a vida de mulheres de várias idades e em várias situaçōes e condiçōes.

Em relaçăo à literatura, foi, também, a partir da família e de sua primeira professora que Adelia se desenvolveu enquanto leitora. Ela conta que iniciou sua fase de escrever poemas nas escolas onde trabalhou. Inicialmente, seus poemas abordavam temáticas de cunho ecológico e ambiental, que eram temas que deveriam ser trabalhados nas escolas, e ela viu no poema uma forma de abordar esses assuntos de forma prática. Também gostava de fazer paródias sobre os temas das aulas.

Adelia diz que nunca estudou poesia, que se considera uma leiga sobre assuntos técnicos referentes ao gênero, e tudo o que sabe sobre poemas, aprendeu lendo poemas de outros poetas. Apesar disso, é possível perceber um rigor nas suas criaçōes literárias.

Quando perguntada sobre o porquê de escrever, a poetisa deu a seguinte resposta:

\begin{abstract}
Porque tenho essa preocupaçăo de deixar um recado, porque um dia eu náo vou mais estar aqui, mas meu recado vai estar. Eu tenho preocupaçăo também que esse recado seja o mais claro possível, que ninguém tenha a obrigaçáo de desvendar, de tentar quebrar a cabeça para saber o que a Adelia quis dizer com isso. [...] Eu năo tenho sonho que o mundo conheça meus livros. A partir do momento que você escreveu e lançou, eles năo săo mais seus, é do mundo, entăo eu tenho essa preocupaçăo. É para ficar a minha marca para os meus netos dizerem futuramente "alguém fez alguma coisa". E se alguém hoje gostar ou năo gostar, criticar, elogiar, para mim nada a ver, tô nem aí. Eu quero mais é escrever. Eu vejo uma obrigaçăo minha em registrar alguma coisa de tudo o que eu aprendi. (MATOS, 2018c).
\end{abstract}

Adelia utilizou toda esta inspiraçăo e vontade de escrever para compor um trabalho literário sobre a mulher, trazendo seu conhecimento para essa produçăo, que diz respeito às mulheres e meninas do passado e do presente, bem como mulheres que sofrem e outras que săo felizes.

A autora percebia desde criança atitudes que evidenciavam a superioridade da figura masculina, e năo entendia aquilo. Foi observando sua realidade que Adelia iniciou suas reflexóes a respeito do modo como a mulher era tratada pelos outros. Em sua juventude, sua indignaçâo se acentuava, em decorrência das inúmeras situaçôes vividas por ela e suas irmăs, principalmente.

Conta ela que a juventude foi cercada por episódios de supremacia masculina, os quais eram legitimados pela sociedade em geral, cabendo pouco espaço para discussōes. Simone de Beauvoir (1970, p. 9), uma importante filósofa das discussōes sobre o papel da mulher em sociedade, postula em seu livro $O$ segundo Sexo que "O homem representa a um tempo o positivo e o neutro, a ponto de dizermos 'os homens' para designar os seres humanos [...]. A mulher aparece como o negativo, de modo que toda determinaçăo lhe é imputada como limitaçăo, sem reciprocidade". 
Foi principalmente na Universidade que os debates sobre a mulher começaram, o que iniciou, também, sua busca por estudar a fundo sobre esse assunto. A partir do surgimento da Lei 11.340, de 7 de agosto de 2006, popularmente conhecida por Lei Maria da Penha, as discussóes se intensificaram. Foram proporcionados eventos sobre mulheres, grupos de estudos dentro e fora da Universidade, em parceria com outras instituiçóes. Além disso, Adelia teve o auxílio de outras professoras para iniciar seus estudos na questăo de gênero.

Esse aspecto é lembrado até hoje pelas pessoas da Universidade quando se fala no nome da poetisa. O professor Dr. Aumeri Carlos Bampi relembrou os feitos de Adelia enquanto professora da UNEMAT.

Dentro dessa formaçăo em Pedagogia ela foi também sempre uma pessoa que se dedicou à questăo de gênero. Ela fez discussóes muito importantes aqui, foram várias noites de estudos interdisciplinares em relaçăo à questăo da mulher, sobre a questăo da violência, da arte, das várias situaçóes que envolvem o público feminino, que é um público da educaçăo em sua maioria. Mas também com temas que năo se fixavam apenas nessa questăo acadêmica, ela tratou de temas relacionados a essa situaçăo da mulher envolvendo várias concepçôes na sociedade, trazendo pessoas da área jurídica, da área do trabalho, da arte, da religiăo, porque era uma questăo importante. (BAMPI, 2018).

Imprime-se, entăo, a importante atuaçấo de Adelia frente às questôes da mulher, a qual movimentou debates, como lembrado pelo prof. Dr. Aumeri, na sociedade sinopense, que foi constituída também sob um sistema patriarcal.

Ela conseguiu fazer o seu trabalho de discutir questóes de gêneros quando, por exemplo, nem se discutia isso na sociedade brasileira, ou a discussăo era ainda incipiente, inicial, nem acontecia. E ela foi muito provocadora e também provocativa aqui no contexto sinopense. Era uma cidade que, querendo ou năo, também se instalou com uma visâo muito patriarcal, entâo eu diria que a professora Adelia tem uma visăo importantíssima do ponto de vista da intelectualidade, de questionar todas essas raízes implantadas aqui, da forma com que a sociedade se desenvolveu, e também dentro da Universidade, porque aqui dentro da Universidade se replicavam essas formas patriarcais. (BAMPI, 2018).

O professor Doutor Josivaldo Constantino dos Santos reforça essas lembranças das mobilizaçôes de Adelia:

E ela sempre foi envolvida com questóes de gênero sim, ela sempre foi uma defensora dos direitos das mulheres. Eu lembro que em momentos anteriores a Adelia estava participando de movimentos na cidade, [...] ela se reunia com promotoras, com advogadas, com médicas, com outras mulheres, e sempre fazia um evento sobre mulheres na UNEMAT. (SANTOS, 2018).

Com todo esse arcabouço teórico constituído por todos os anos de estudo sobre a mulher, Adelia uniu seu conhecimento com o desejo de fazer poesia, o que lhe rendeu uma série de poemas que expressam o ser mulher, englobando aspectos sociais e cotidianos, da infância, juventude e velhice. 
Eu me inspiro em dores das mulheres, mesmo dores que náo apareçam. Eu vou na igreja, vou nos lugares e fico analisando as mulheres, por que elas estăo com esses traços. Algumas você percebe que tem traços de alegria, de felicidade no rosto, de vida feliz. E outras tem o traço triste. E eu as vezes abordo elas e pergunto o que eu posso e assim que a gente começa a perguntar, elas văo se abrindo. (MATOS, 2018c).

Dessa forma, percebe-se a importância de Adelia para a sociedade sinopense, pois contribuiu de modo significativo, primeiramente como professora das escolas e posteriormente na UNEMAT, onde se desdobrou pela instalaçăo permanente da Instituiçăo em Sinop, além de ter movido importantes discussóes e debates sobre a mulher em Sinop, gesto valoroso para a comunidade sinopense. Adelia foi membra da Academia Sinopense de Ciências e Letras (ASCL), associaçăo criada em 2008. De acordo com o site oficial da Academia, trata-se de uma entidade com a funçâo de motivar a literatura nos diversos ambientes, de promover e divulgar a produçăo dos membros, promover concursos literários e apoio nas diversas manifestaçōes culturais de Sinop.

Adelia é uma representante da produçâo literária sinopense atual. Seus poemas tratam da mulher nas suas diversas realidades. Através de uma linguagem simples, Adelia elucida questôes do cotidiano e questóes sociais desse sujeito. Seus versos sâo, em sua maioria, rimados, compassados e divididos em estrofes, entretanto, é possível encontrar poemas em versos livres e sem rimas. Sobre isso, Candido (2006) elucida que a poesia nâo é intrínseca a versos e rimas, ela existe além destes, podendo, inclusive, ser encontrada em gêneros da prosa, por exemplo.

A seguir analisaremos os sentidos de prisâo que săo evidenciados em dois de seus poemas. Antes, porém, é importante destacarmos e explicitarmos o campo teórico que servirá de base para a compreensâo dos sentidos mobilizados nos escritos de Adelia.

\section{A ANÁLISE DO DISCURSO COMO MOLDE ANALÍTICO}

Tendo em vista o surgimento da Linguística nos anos 1916 com a publicaçâo dos escritos de Ferdinand de Saussure, o Curso de Linguística Geral, sabemos que houve uma dicotomia entre língua e fala. A língua era considerada um sistema abstrato de regras, passíveis de serem analisadas e sistematizadas por serem consideradas estáveis. Já a fala nâo foi inserida nos estudos de Saussure por ser considerada um processo individual, instável, dependente das condiçōes de enunciaçăo de cada indivíduo (INDURSKY, 1998). Pêcheux, entretanto, percebendo a necessidade da historicidade na constituiçâo da linguagem, formula, no final dos anos 1960, a Análise do Discurso (doravante AD), disciplina esta que, segundo Baronas (2008, p. 11) “consiste em uma teoria năo-subjetiva da linguagem que concebe o sujeito náo como o centro do discurso, mas como sujeito cindido pelo inconsciente e interpelado pela ideologia". No entanto, Pêcheux reformulou conceitos da Linguística, como sabemos, e emprestou, reformulando-os também, noçōes de outras áreas, como da Psicanálise, do Materialismo Histórico e da Teoria do discurso, representada por Orlandi (1983, p. 100) como "a determinaçăo histórica dos processos semânticos". Além destas, a AD é atravessada por uma teoria do sujeito derivada da Psicanálise. No entanto, como lembra Orlandi (2015a, p. 15) "năo se trata de se fazer uma adiçăo ingênua dos três para desembocar em uma teoria do discurso", mas sim de um trabalho de reformulaçăo dos conceitos para que surgisse a Análise do Discurso. 
A Análise do Discurso é um campo de conhecimento que observa a linguagem para além de suas questōes estruturais. Para Orlandi (2004) o trabalho da Análise do Discurso náo é compreendido como a aplicaçáo dos conceitos das ciências sociais na Linguística ou vice-versa, mas uma reelaboraçăo dessas disciplinas para desembocar na $A D$, buscando relacionar a linguagem aos seus elementos exteriores. De acordo com Oliveira (2005, p. 12) “a Análise de Discurso opera com a năo-transparência de uma linguagem que náo fixa os sentidos no texto, mas que significa e produz sentidos, os quais săo socialmente construídos", ou seja, os sentidos năo sâo construídos no texto, mas na relaçấo do texto com sua exterioridade. O enunciado significa quando relacionado às suas condiçôes de produçấo, às suas formaçôes discursivas e ideológicas, à consideraçăo do sujeito clivado, e, a partir daí, o enunciado passa a ser encarado como discurso.

O trabalho da $\mathrm{AD}$ está intimamente ligado aos sentidos e à interpretaçăo. De acordo com Orlandi (2015b) a interpretaçâo é condiçâo do ser humano. Estando sujeitos à linguagem e à história, a interpretaçăo deriva dessas relaçōes. Para Orlandi (2015b, p. 24) "compreender é saber como um objeto simbólico (enunciado, texto, pintura, música, etc.) produz sentido. É saber como as interpretaçōes funcionam". Além disso, para a autora (2004) o sujeito mostra sua direçâo no momento em que significa, pois a interpretaçâo está determinada pelo lugar em que o sujeito que interpreta ocupa. Ou seja, a interpretaçâo está profundamente relacionada às formaçôes discursivas e ideológicas do sujeito.

\subsection{DISCURSO E IDEOLOGIA}

A Análise do Discurso se diferencia dos outros campos teóricos da Linguística por se debruçar sobre o discurso enquanto objeto de estudo, ao passo que outras disciplinas colocam nessa posiçăo, a língua, a fala, a estrutura da palavra. No entanto, a linguagem tem papel fundamental na teoria do discurso, por ser a partir da língua que o sujeito significa, produz sentido no mundo. Porém, a maneira com que observamos a língua na $A D$ é diferente, pois consideramos que "o dizer tem história" (ORLANDI, 2015b, p. 47), ou seja, todo dizer já vem carregado de sentidos múltiplos, a língua náo é neutra e transparente, mas sim prenhe de sentidos que nâo estâo em nossa alçada controlar. Partindo disso, entendemos que o discurso năo é igual à língua ou à fala ou ao texto, mas tem relaçăo com estes na medida em que é a partir deles que faz aparecer o discurso.

Para Pêcheux (2010a, p. 81) o discurso é considerado "efeito de sentidos entre locutores". Brandāo (2012, p. 11) conceitua o discurso como "o ponto de articulaçấo dos processos ideológicos e dos fenômenos linguísticos", ou seja, o discurso é a materialidade da ideologia na língua, ele é o produto do encontro entre língua e ideologia.

Orlandi (1983) define uma tipologia de discursos, sendo eles o discurso autoritário, o discurso polêmico e o discurso lúdico. Essa tipologia é definida principalmente sob como os interlocutores se relacionam e como se relacionam com o objeto do discurso. O discurso autoritário é aquele em que só um locutor fala e o ouvinte deve ouvir, sem haver possibilidades de leitura polissêmica. Já em relaçấo ao discurso polêmico, procura-se controlar a polissemia, havendo pouco espaço para várias interpretaçôes. Outros sentidos sâo possíveis, mas săo guiados pelo sujeito que detém a relaçăo de força mais poderosa no momento de interlocução. 0 discurso lúdico é o discurso em 
que a polissemia é aberta, năo há relaçôes de força maiores ou menores entre os locutores, logo os sentidos săo livres para se constituírem. Este último tipo de discurso é o qual acreditamos se encaixar em nosso trabalho aqui empreendido, pois se trata de um discurso poético, no qual, se for levado em conta no seio de sua técnica de análise (teoria literária), já nos é sabido que o sentido do poema, em relaçăo a outros gêneros literários, é mais aberto, há maior possibilidade de produçâo de sentido.

Brandāo (2012, p. 30) define que "[...] nâo há um discurso ideológico, mas todos os discursos o sâo. Essa postura deixa de lado uma concepçâo de ideologia como "falsa consciência" ou dissimulaçăo, mascaramento, voltando-se para outra direçâo ao entender a ideologia como algo inerente ao signo em geral". Na AD, descola-se esse conceito da ideia de visăo de mundo e concepçăo de ideias. A ideologia é o mecanismo que mantém os sentidos, é por ela que, de acordo com Orlandi (2004, p. 31) “se naturaliza assim o que é produzido pela história: há transposiçāo de certas formas materiais em outras [...], há simulaçăo (e nâo ocultaçăo de "conteúdos") em que sâo construídas transparências [...] para serem interpretadas".

Orlandi (2004, p. 28) nos esclarece que: "[...] nâo há relaçăo termo-a-termo entre as coisas e a linguagem. Sâo ordens diferentes, a do mundo e a da linguagem. Incompatíveis em suas naturezas próprias. A possibilidade mesma da relaçâo mundo-linguagem se assenta na ideologia".

Sendo assim, como defendido por Pêcheux (1995), é através da ideologia que temos a ideia de que o mundo é tal como ele nos é apresentado, é pela ideologia que temos a ilusăo de que as palavras designam as coisas em decorrência da ilusăo da transparência da linguagem.

\subsection{CONDIÇÕES DE PRODUÇÃO}

Todo discurso é produzido a partir de uma situaçăo histórica e ideológica. Para a Análise do Discurso, prestar atençấo a essa característica é fundamental, pois o dizer é definido a partir das chamadas Condiçôes de Produçâo. Orlandi (2015a, p. 17) resume esse conceito formulando que

As condiçôes de produçăo incluem, pois, os sujeitos e a situaçăo. A situaçăo, por sua vez, pode ser pensada em seu sentido estrito e em seu sentido lato. Em sentido estrito ela compreende as circunstancias da enunciaçăo, o aqui e o agora do dizer, o contexto imediato. No sentido lato, a situaçăo compreende o contexto sócio histórico, ideológico, mais amplo.

De acordo com Brandâo (2012) entendemos que esse conceito diz respeito ao contexto em que o discurso é produzido, levando em conta os sujeitos e suas posiçóes, a ideologia dominante no momento de construçâo do discurso, as formaçóes discursivas e todas as relaçôes que determinam a produçăo do discurso. As condiçôes de produçâo dizem respeito a toda a carga histórica e ideológica de determinado momento, bem como do inconsciente que atua sobre o sujeito, que năo é dono de seu dizer, portanto só enuncia o que lhe é possível naquele momento social, histórico e ideológico, ou seja, naquelas condiçôes de produçấo. 


\subsection{FORMAÇÕES IDEOLÓGICAS, DISCURSIVAS E IMAGINÁRIAS}

Segundo Brandâo (2012), através da articulaçăo entre ideologia e discurso surgem as formaçōes ideológicas (FI) e Formaçōes Discursivas (FD). Conforme Pêcheux (2010b, p. 310) “uma FD nâo é um espaço estrutural fechado, pois é constitutivamente "invadida" por elementos que vêm de outro lugar (isto é, de outras FD) que se repetem nela, fornecendo-lhe suas evidencias discursivas fundamentais".

Para Brandăo (2012) uma formaçaáo ideológica tem intrínseca a ela várias formaçôes discursivas. Essas formaçōes discursivas constituirăo as formaçôes ideológicas. Como pontua Orlandi (2015a), as formaçōes discursivas projetam, através da língua, as formaçôes ideológicas, ou seja, é a partir das posiçôes do sujeito, inseridas nas formaçôes ideológicas, que, por sua vez, determinam as formaçôes discursivas, que o dizer adquire um sentido e năo outro.

Num determinado momento histórico e no interior mesmo desses aparelhos, as relaçóes de classe podem caracterizar-se pelo afrontamento de posiçôes políticas e ideológicas que se organizam de forma a entreter entre si relaçóes de aliança, de antagonismos ou de dominaçâo. Essa organizaçâo de posiçóes políticas e ideológicas é que constitui as formaçôes ideológicas (BRANDÂO, 2012, p. 47).

Tomé (2014, p. 363) discorre que "O sujeito, quando fala, adere à sua formaçăo discursiva, se assujeita; é na prática discursiva que esse movimento se mostra", portanto, é um movimento involuntário e psíquico, năo nos damos conta deste funcionamento.

Os sujeitos, no discurso, ocupam lugares. Esses lugares săo representados, de acordo com Brandăo (2012, p. 44) “por uma série de 'formaçôes imaginárias' que designam o lugar que destinador e destinatário atribuem a si mesmo e ao outro, a imagem que eles fazem de seu próprio lugar e do lugar do outro", ou seja, somos representáveis por imagens que o outro faz de nós e de si próprio e que nós fizemos do outro e de nós mesmos. As formaçōes imaginárias, segundo Orlandi (2015b), sâo constituídas de relaçôes de poder, que compreendem quem tem mais poder no discurso, quem tem o dizer mais valioso. Esses processos de significaçâo sâo feitos inconscientemente, determinados pela ideologia dominante. Também fazem parte das formaçōes imaginárias as relaçôes de sentidos - o discurso tem relaçăo com outros discursos, um discurso năo é fechado em si próprio, ou seja, segundo Orlandi (2015b, p. 37), "nâo há [...] começo absoluto nem ponto final para o discurso".

Todo dizer vem necessariamente definido pelas formaçōes imaginárias. Săo essas formaçóes que definem o modo como enunciamos, como buscamos significar para o outro, como estruturaremos nosso dizer para buscar o sentido que queremos que o outro faça de nosso discurso. É possível identificar essas relaçōes nos postulados de Orlandi (2015b, p. 40), onde é definido que "o imaginário faz necessariamente parte do funcionamento da linguagem. Ele é eficaz. Ele năo "brota" do nada: assenta-se no modo como as relaçóes sociais se inscrevem na história e săo regidas, em uma sociedade como a nossa, por relaçôes de poder". 


\subsection{O SUJEITO NO DISCURSO}

Para a $A D$, diferentemente de outros campos teóricos, o sujeito năo é considerado um indivíduo dono do seu dizer, ele é interpelado pela ideologia e pelo inconsciente, "a ideologia se manifesta (é falada) através dele" (MUSSALIM, 2006, p. 134). Nessa perspectiva, o sujeito tem apenas a ilusăo de que tem autonomia sobre tudo o que diz, ele acredita que tudo o que é por ele enunciado, faz sentido da maneira que ele deseja, ou seja, o sujeito tem a ilusăo da transparência da linguagem. Orlandi (2015b, p. 33) contribui para esse entendimento quando pontua que "embora se realizem em nós, os sentidos apenas se representam como originando-se em nós: eles săo determinados pela maneira como nos inscrevemos na língua e na história e é por isto que significam e năo pela nossa vontade". Ainda para Mussalim (2006, p. 107), o sujeito é "definido em funçâo do modo como ele se estrutura a partir da relaçâo que mantém com o inconsciente, com a linguagem". Em relaçăo ao assujeitamento, Orlandi (1999) considera que o sujeito só é sujeito quando se utiliza da língua para fazer sentido, ou seja, é através do assujeitamento ao simbólico que o indivíduo passa a ser sujeito. Sobre este processo o sujeito năo tem controle, pois é algo que acontece independentemente da vontade dele, é trabalho do subconsciente.

De acordo com Orlandi (2015a, p. 18),

[...] segundo as relaçôes de força, o lugar social do qual falamos marca o discurso com a força da locuçăo que este representa [...]. Cada um desses lugares tem sua força na relaçáo de interlocuçăo e isto se representa nas posiçôes sujeito. Por isso essas posiçóes năo săo neutras e se carregam do poder que as constitui em suas relaçóes de força.

\subsection{INTERDISCURSO E MEMÓRIA DISCURSIVA}

Todo discurso tem necessariamente relaçăo com outros discursos já produzidos em outro lugar e em outros tempos. Nada é criaçăo individual, pois tudo o que enunciamos já foi dito em outra oportunidade. Estas consideraçôes têm relaçăo com a Memória Discursiva e o Interdiscurso, que săo a memória do dizer. Nesse sentido, damos voz a Orlandi (2015a, p. 20) quando materializa que "O interdiscurso é irrepresentável. Ele é constituído de todo dizer já-dito. Ele é o saber, a memória discursiva. Aquilo que preside todo dizer". Para a mesma autora (2015b, p. 28), o interdiscurso é "o saber discursivo que torna possível todo dizer e que retorna sob a forma do pré-construído, o já-dito que está na base do dizível, sustentando cada tomada da palavra", entâo, é o interdiscurso, a memória discursiva que dăo pano para a enunciaçăo. A memória discursiva determina o dizível em determinada condiçáo de produçāo, ela é a memória do dizer, e é nela que o sujeito busca as referências para sua enunciaçăo, processo que ocorre inconscientemente.

Pêcheux (1999, p. 52) conceitua memória discursiva como "aquilo que, face a um texto que surge como acontecimento a ler, vem restabelecer os "implícitos" (quer dizer, mais tecnicamente, os pré-construídos, elementos citados e relatados, discursos transversos, etc)". Sob esta ótica, a memória discursiva vem a ser tudo o que está disponível ao sujeito, todos os elementos já acontecidos que estăo à disposiçấo para a produçâo do discurso, e o Interdiscurso é o movimento da memória discursiva, é a memória que o sujeito lança măo para enunciar. O interdiscurso năo deixa aparecer o 
já-dito, que estabiliza os sentidos aceitos socialmente. É pelo interdiscurso, através de um trabalho ideológico, que ocorre a homogeneizaçâo das significaçôes. Como explica Oliveira (2005, p. 13):

[...] o interdiscurso consiste no pré-construído e na articulaçăo. O pré-construído, articulado pela ideologia, é a característica de qualquer formaçăo discursiva que produz o efeito - através do hábito ou do uso - do 'já dito', que nos dá a impressăo do fato 'já conhecido', 'já sabido por todos'.

Compreendemos, nesse sentido, que o Interdiscurso e a Memória Discursiva estabilizam os sentidos, dăo forma ao que conhecemos. Esses conceitos trabalham juntamente com a ideologia, que produz o efeito de apagamento desse pré-construído.

Tomando por base todo o arcabouço teórico formado até aqui, debruçar-se-á sobre a análise discursiva de dois poemas de Adelia sobre a mulher, escolhidos por levarem em conta questôes sociais que dizem respeito à constituiçăo da subjetividade da mulher socialmente.

\section{AS MULHERES DE ADELIA}

Adelia escreve da posiçáo de uma mulher que foi construindo seu conhecimento sobre a condiçăo feminina em sociedade, perpassando pelas transformaçóes das relaçôes de trabalho e afetivas, sempre buscando enxergar as adversidades infiltradas na existência desse sujeito. A autora escreve sobre a mulher em diferentes fases, desde a infância até a velhice, representando o cotidiano dessas personagens, que passam por momentos felizes e alegres, mas também momentos tristes ou de temor. Em nosso empreendimento, selecionamos dois poemas para a análise, cujos recortes retratam situaçôes em que a mulher é tomada como objeto de dominaçăo masculina. A seleçâo destes corpora ocorreu dada a importância de se estudar essas representaçôes. Os poemas escolhidos se utilizam da língua e se relacionam com a história para significar, e é esse funcionamento que buscaremos observar, ou seja, procuramos compreender de que forma os poemas de Adelia produzem sentido, relacionando os dizeres com a sociedade.

As condiçōes de produçăo dos poemas levam em conta as questōes ideológicas que compreendem a sociedade patriarcal que objetifica a mulher. Quando se analisa a palavra "mulher" (ou suas derivaçóes) em nosso corpus, todo o pré-construído que funciona sobre esse sujeito produz sentido na materialidade aqui trabalhada. Por este motivo a Análise Discurso relaciona a língua à história (ORLANDI, 2015b). Dessa forma, Massmann e Brasil (2017, p. 49) discorrem que "os sentidos postos em funcionamento se sustentam em diferentes condiçōes de produçáo e fazem circular formaçóes discursivas diversas que revelam a persistência de um conflito em torno da mulher". Nos corpora selecionados para a presente análise, o que desponta de maneira bastante enfática sáo os sentidos de prisōes. Mesmo quando a palavra "prisáo" e suas derivaçóes năo aparecem, esses sentidos sâo mobilizados por outros elementos linguísticos, e é sobre eles que será dado enfoque nas análises. Serăo apresentados os poemas, no intuito de compreender de que forma se constituem os efeitos de sentido de prisâo na discursividade da mulher. Para uma melhor compreensâo, os versos analisados foram destacados nos dois poemas que serâo apresentados a seguir. 
Casas enfileiradas

Fazenda de grande porte

Vasto, vasto cafezal

Logo depois canavial

No Paraná do norte.

Cada casa uma família

A família e sua história

Donde vinha o que trazia

$O$ que ali se fazia

Marcando uma trajetória.

Na casa número três

Morava um viúvo esquisito Janelas e portas fechadas

Menina ali, aprisionada

Sem poder dar um só grito.

Mobília daquela casa

Quase nem existia

Uma cama, um fogăo

Uma mesa, um caixotăo

Cadeira improvisando pia.

Quando a mudança chegou

Com ela veio Meirita

Menina, moça, morena

Ainda muito pequena

Com seu vestido de chita.

Entrava dia e saía

De Meirita nem sinal

Silenciosa e cabreira

Passava a semana inteira

Num sumiço sem igual.

O viúvo saía bem cedo

Ela ficava sozinha

Prisioneira encarcerada

Toda desconfiada

E ele voltava à noitinha

\subsection{MEIRITA}

É que Meirita dormia

Com o pai na mesma cama

Obrigada a se despir

Fazer suas vontades e sorrir

Depois silenciar o seu drama.

Naquela noite a lamparina

Foi posta na cabeceira, acesa

Sem querer testemunhava

Um "pai" que violentava

Uma inocente indefesa.

Por conta dos movimentos

A lamparina caiu, incendiou

Quanto mais Meirita gritava

Tanto mais se queimava

E a vizinhança chegou.

A notícia se alastrou

Para o espanto geral

O "pai" continuou sua rotina

O azar foi só da menina

Nunca se viu nada igual.

Meirita ficou de cama

Alguns dias dolorida

Se mostrava envergonhada

Quando era visitada

Por ser assim sua vida.

Seu braço direito ficou

Pra sempre no corpo grudado

Uma indagaçáo no ar

Fazia-nos acreditar

O crime foi consumado.

Por onde andará Meirita?

Dois mil e doze. Agora?

Homens que monstros săo

Ela mártir, por que năo?

Meiritas de hoje e de outrora.

(MATOS, 2014, p. 61-63). 
O poema explicita o abuso sexual sofrido por uma menina, em que seu abusador era seu pai. Os dois moravam numa fazenda, vivendo uma vida reservada, um tanto misteriosa. A menina era silenciada pelo pai, pois a vizinhança pouco via Meirita. Levando em conta que o sujeito "tem existência em um espaço social e ideológico, em um dado momento da história e năo em outro" (FERNANDES, 2008, p. 22), ou seja, o sujeito ocupa vários lugares na discursividade, no presente discurso, o sujeito dos versos fala da posiçấo de menina interiorana, possivelmente em um tempo passado, visto que o texto fala sobre o uso de lamparinas, objeto que praticamente perdeu o uso com o advento da energia elétrica. Por estas condiçōes de produçáo, fica mais marcado o patriarcalismo, por ser mais evidente nos tempos passados essa maneira da sociedade se constituir.

Inicialmente buscaremos focalizar a superfície linguística e a trama de sentidos que săo movidos por ela, tendo em mente que "a linguagem é estrutura e acontecimento, tendo assim de existir na relaçâo necessária com a história (e com o equívoco)" (ORLANDI, 2004, p. 12). Tomaremos o método de análise empreendido no texto $A$ linguagem em revista: a mulher-fêmea, de Eni Orlandi (2003), onde a autora analisa os deslizes de sentido das marcas discursivas, bem como dos substantivos, adjetivos e verbos. Essa metodologia será replicada nos dois poemas aqui analisados. Em Meirita, os sentidos de prisâo săo observados desde o começo do poema.

Casas enfileiradas: o desenho de fileiras forma grades, utilizadas para aprisionar. Em materialidades linguísticas aparentemente inocentes, têm-se a formação dos sentidos predominantes no poema.

Obrigada a se despir: nesta construçâo linguística observamos as relaçôes de poder que funcionam sobre a mulher. Seu pai obriga Meirita a "fazer suas vontades e sorrir", ou seja, neste discurso funcionam tanto as forças das relaçôes paternas para com os filhos quanto a força do homem sobre a mulher, que acredita ser de seu direito obrigar a filha-mulher a satisfazer seus desejos, sem reclamar e sorrindo.

O azar foi só da menina: aqui é possível observar o prestígio que os homens têm socialmente. É uma representaçâo da sociedade patriarcal, onde o homem é legitimado a fazer o que imagina ser de seu direito, sobrando apenas para a mulher lidar com as marcas das violências de que fora alvo, visto que "O "pai" continuou sua rotina", ou seja nâo foi o homem que sofreu com os crimes cometidos por ele.

Passemos agora à análise de alguns substantivos, adjetivos e verbos, que mobilizam sentidos para o corpus aqui analisado.

\section{SUBSTANTIVOS}

Prisioneira encarcerada: Nesta marca linguística os sentidos de prisâo săo deixados bem claro, além de serem reforçados pelos substantivos-adjetivos que apresentam dupla função nesta construção.

\section{ADJETIVOS}

Silenciosa e cabreira: estes adjetivos deixam evidente toda a construçâo social exigida da mulher. Em sua constituiçáo como sujeito inscrito na história, as formaçôes imaginárias sobre a mulher esperam desse sujeito a discrição. A mulher deve se portar 
de forma que sua existência năo abale as estruturas patriarcais, além disso, năo deve se rebelar, pois ao destruir os preceitos de silenciosa e cabreira, deixa de ser considerada como uma mulher respeitável. Outros deslizes para os adjetivos que retomam o sentido de prisâo sâo: Janelas e portas fechadas / Toda desconfiada.

\section{VERBOS}

Depois silenciar o seu drama: o silêncio, neste caso, é o de năo ter voz. Como observado na maioria dos tempos sobre a mulher, o silêncio fez parte da maior parte da história desse sujeito. Nâo é diferente no poema aqui analisado, visto que a violência sofrida por Meirita deve ser silenciada. Para os verbos, as marcas de prisăo săo: Um "pai" que violentava / Sem poder dar um só grito.

Uma das primeiras prisóes que aparecem no poema é a prisăo da voz. A menina do poema năo pode falar, năo pode denunciar, pois depende do pai para sobreviver. Nesse sentido aparece mais uma forma de prisâo: a financeira. Além disso, as relaçôes de poder que operam entre pais e filhos também funcionam neste corpus, pois, por mais que o pai de Meirita seja um abusador, as imagens da relaçăo pais-filhos produzem o sentido de que o filho precisa respeitar e obedecer aos pais, pois é deles a funçâo de ensinar, por supor-se ser deles o conhecimento sobre a vida. Nessa perspectiva, a formaçáo imaginária, para Mussalim (2006, p. 138) “faz parte das condiçôes de produçâo de um discurso, na medida em que as imagens que o sujeito vai construindo ao enunciar vâo definindo e redefinindo o processo discursivo" e săo essas imagens que funcionam no processo discursivo em questăo.

Apesar de Meirita năo ser a causadora dos sofrimentos por ela passados, a sequência discursiva: Se mostrava envergonhada / Quando era visitada / Por ser assim sua vida demonstram a vergonha sentida pela mulher. Colocando esse dizer em relaçăo à história, percebemos que essa sensaçáo de vergonha é imposta às mulheres desde o nascimento, visto que as meninas săo ensinadas a esconderem seus corpos, suas vontades.

Agora, passemos à análise do último poema constituinte de nossos corpora. 


\subsection{BARGANHANDO O SAGRADO}

Todo processo possui

Um fim, um meio, um começo

Isso Vênus sabia

Como também refletia

Mas tudo tem o seu preço.

Escrevia, lia, discutia

Defendendo seu pensar

Andava sempre adiante

Com ideias abundantes

Firme em seu avaliar.

Vênus lia e pensava

Depois ia a campo checar

Relata o que o livro afirma

É fato, ela confirma

Se isola pra comparar.

Entre uma leitura e outra

Ao cotidiano se reporta

Sempre com mais certeza

Que o homem e sua esperteza

De sua sepultura cava a porta.

Lia sobre mulher

E ficava horrorizada

Sobre mulher escrevia

E mais lhe comovia

A mulher fragilizada.

O homem impóe orgulhoso

Várias formas de poder

A se comparar com a mulher

Tudo o que ele quer

É sua força exercer.

Entre hipóteses e diagnósticos

Vênus já garantia:

Quando o homem quer

Arrisca comprar a mulher

Explorando sua companhia.
Nâo tardou ela se viu

Nas redes de sua teoria

Osni que era ateu

Ir à missa prometeu

Há anos que nâo fazia.

É lógico que era estranho Porém, ela náo se deu conta

Osni falou baixinho

Depois vamos ao Espetinho,

A comida lá já está pronta.

Para a Igreja os dois se foram

Em seguida para o Espetinho

Chegando em casa ela viu

Quando ele se despiu

O tamanho de seu golpinho.

Ele a chamou para o quarto

E ficou bem nu lhe aguardando

Dizendo que viesse pagar

Por ele ter ido orar

Sem saída ela foi se arrumando

Osni atingiu o ponto alto

Ela nada sentiu de emoçáo

Perde o sono e se agita

Irritada nâo acredita

Naquela funesta armaçăo.

Como caiu na armadilha

De Osni, seu maridinho?

Sentindo-se muito mal

Se viu uma pitada de sal

Sobre aquele espetinho.

Que sensaçāo de impotência

Ser usada, barganhada

Sua condiçăo de mulher

Naquele momento requer

Uma atitude a ser tomada.

(MATOS, 2014, p. 87-89). 
Neste poema ocorre um deslize na maneira em que o sujeito-mulher se coloca no mundo. Inicialmente, Vênus (a mulher) é ativa na busca por conhecer a situaçăo das outras mulheres. Entretanto, o texto acaba por produzir uma paráfrase quando retoma os mesmos sentidos de aprisionamento que causam a submissividade observada no poema anterior. Ou seja, há um conflito de discursos. Esse fenômeno pode ser compreendido quando Orlandi (2004, p. 30) expressa que "necessariamente determinado por sua exterioridade, todo discurso remete a um outro discurso, presente nele por sua ausência necessária", ou seja, um discurso nunca é fechado nele mesmo, mas tem sempre relaçăo com outros discursos.

O sujeito-mulher, neste discurso, se apresenta como alguém consciente dos problemas sociais que rodeiam as mulheres, entretanto, a memória năo é apagada, e estes mesmos sentidos percebidos pela mulher do discurso, se constituem nela. Pêcheux (1999, p. 56) nos ajuda nessa compreensâo pontuando que:

[...] uma memória náo poderia ser concebida como uma esfera plena, cujas bordas seriam transcendentais históricos e cujo conteúdo seria um sentido homogêneo, acumulando ao modo de um reservatório: é necessariamente um espaço móvel de divisôes, de disjunçóes, de deslocamentos e de retomadas, de conflitos de regularizaçăo... Um espaço de desdobramentos, réplicas, polêmicas e contradiscursos.

Por este caráter heterogêneo e conflituoso da memória, é que ela nâo é esquecida e, pelo contrário, traz sentido aos novos sentidos formados. Dessa forma, é por isso que Vênus năo conseguiu apagar da trama dos seus conflitos as imagens que remetem à constituiçăo do sujeito mulher como alguém que deve sempre ser submissa, porque a memória está sempre lá. A memória nâo se apaga, pois é condiçăo da constituiçấo de novos significados. Orlandi (1999, p. 65) esclarece que "falar é esquecer. Esquecer para que surjam novos sentidos, mas também esquecer apagando os novos sentidos que já foram possíveis mas foram estancados em um processo histórico", como é o caso da tentativa dos novos sentidos sobre a constituiçâo da mulher neste poema, que acaba retornando ao mesmo. Passemos agora à análise das marcas linguísticas do poema.

Escrevia, lia, discutia: Estas açōes dizem respeito aos estudos que Vênus fazia sobre a posiçấo da mulher em sociedade e sobre as relaçôes de poder exercidas pelo homem sobre o sujeito-mulher. Aqui temos a falsa impressáo de que Vênus, por estudar e conhecer o funcionamento da existência da mulher, vai se desvencilhar dessas prisôes.

Năo tardou ela se viu / Nas redes de sua teoria: compreende a dificuldade de se livrar das amarras que cerceiam as mulheres, que, mesmo conhecendo a realidade que lhe diz respeito, se encontra nas mesmas condiçōes. A escolha lexical 'redes' mobiliza os sentidos de aprisionamento.

Dizendo que viesse pagar: o homem se sente no direito de cobrar uma recompensa da mulher quando faz algo que lhe agrada.

Sem saída ela foi se arrumando: a prisāo é materializada no verso, onde 'sem saída' demonstra a prisâo velada. O homem nâo usou de força para exercer seu poder, mas exerceu o seu "direito" enquanto homem de cobrar o que a sociedade sempre legitimou como sendo seu. 
Irritada năo acredita: aqui a mulher se sujeita de forma diferente da mulher do poema anterior, pois se coloca como ativa nas perspectivas, mesmo que náo tenha tido condiçôes de subversâo a esta situaçăo.

Como caiu na armadilha: armadilha, para este caso, traz uma carga semântica que mobiliza o sentido de prisâo escondida.

Uma atitude a ser tomada: Vênus, ao contrário da outra mulher analisada anteriormente, se coloca numa posiçấo de luta contra a condiçâo da mulher como um ser submisso às vontades do homem e sem perspectiva de mudança.

\section{SUBSTANTIVO}

Que sensaçăo de impotência: esse substantivo mostra a revolta do sujeito-mulher frente a opressâo de sua vontade. Impotência é um substantivo que impera no que diz respeito à construçâo da mulher socialmente. Outros deslizes para as prisôes săo observados em: O homem impóe orgulhoso / Várias formas de poder.

\section{ADJETIVO}

A mulher fragilizada: Vênus, estudando sobre a realidade da mulher, enxerga a fragilidade que rodeia esse sujeito. Tem-se a falsa ideia de que, por ela conhecer as tramas vivenciadas pelas mulheres, vai conseguir se desvencilhar dessa condiçăo. Entretanto, as marcas do patriarcado sâo tâo grandes que a fazem estar na mesma condiçáo de fragilizada. Contribuindo com estes sentidos está o orgulho do homem em exercer sua força, como em: O homem impóe orgulhoso.

\section{VERBO}

Ser usada, barganhada: os verbos aqui destacados săo os que sintetizam os sentidos principais do poema, pois o homem agrada a mulher esperando pela sua recompensa, atitude observada em várias situaçōes que dizem respeito à mulher, que a obriga a ser grata por coisas que nâo é sua obrigaçăo. Outros sentidos para a prisăo sâo: Explorando sua companhia.

Vênus, pela sua condiçăo de mulher, se vê nas mesmas situaçōes que eram observadas por ela em suas leituras, ou seja, relacionando essa marca linguística às condiçóes de produçâo desse discurso, a mulher, independentemente de sua posiçấo na sociedade, sempre estará sujeita às prisōes. A prisăo, neste corpus, é a prisăo social. A mulher para este discurso, mesmo sabendo de todas as relaçóes de poder que o homem exerce, nâo consegue se desvencilhar dessas relaçóes, pela configuraçăo social que dita que a mulher deve agradar o marido, mesmo que seja obrigada a fazer o que náo queira. Nesse caso específico, a mulher tem sua sexualidade controlada pelo homem, que, conforme observado pela própria Vênus, é capaz de fazer de tudo para exercer seu poder de dominador. Segundo Telles (2004, p. 337) “O discurso sobre a 'natureza feminina', que [...] se impôs à sociedade burguesa em ascensâo, definiu a mulher, quando maternal e delicada, como força do bem, mas, quando "usurpadora" de atividades que nâo lhe 
eram culturalmente atribuídas, como potência do mal". Essas imagens contribuem para a estabilizaçăo da memória formada sobre a mulher.

O casamento exerce a prisăo fundamental nesse corpus, visto que a mulher delega o controle do próprio corpo às vontades do homem. Em relação ao histórico da mulher, essas relaçōes de dominância sâo observadas principalmente no passado, quando as mulheres muitas vezes eram vendidas para se casarem com o pretendente mais rico que surgisse. A partir disso, por ela ser um objeto adquirido por seu marido, suas vontades nâo eram ouvidas. Entretanto, toda essa história deixa marcas nos sentidos produzidos atualmente. Houveram vários novos sentidos sobre o casamento, no entanto ainda vigora com certa força essa tendência a obrigar as mulheres a fazerem o possível para a manutençăo de seus casamentos, mesmo que năo seja de sua vontade.

\section{CONSIDERAÇÕES FINAIS}

Vimos que a Análise do Discurso observa a linguagem na sua relaçâo com a história, sempre na busca da compreensăo do processo de significaçăo que é posto em funcionamento quando da produçấo de um discurso (MASSMANN; BRASIL, 2017). Nessa perspectiva, a tarefa do analista do discurso năo é simplesmente interpretar, mas compreender como os sentidos se constituem num texto, ou seja, como o texto gera um ou outros efeitos de sentido (ORLANDI, 2001a). Para este campo do saber, a incompletude é condiçăo da produçâoo de significaçăo. Os sentidos năo estâo já-lá, mas se constituem com relaçấo à exterioridade que os inaugura. Orlandi (2001b, p. 20) expressa que "o que chamamos discursividade é justamente a inscriçăo dos efeitos da língua na história", por isso é necessário levar em conta os processos ideológicos em voga no momento da enunciaçâo para que a análise aconteça de forma que se considerem os sentidos como únicos possíveis.

Com este trabalho, buscamos dar ênfase à produçăo literária constituída em Sinop, no intuito de dar prestígio a uma mulher que escreve sobre a mulher, pela importância que este feito tem para as mulheres, que sempre tiveram suas histórias contadas por homens. Além disso, o trabalho objetivou contribuir com as questôes de gênero, e violência contra a mulher, discutindo como se produzem esses sentidos num texto poético.

A partir das análises, objetivamos compreender de que modo se constituem os sentidos sobre a mulher e, percebendo as regularidades dos sentidos de prisăo nas produçóes, procuramos compreender como se formam essa rede de sentidos para as mulheres de Adelia. Percebemos que as prisóes náo acontecem apenas em sentido denotativo, mas em vários sentidos possíveis para a palavra prisăo.

Por fim, este trabalho teve como objetivo, em ampla instância, homenagear a poetisa e professora Adelia Stedile de Matos, que é uma das produtoras do corpo literário sinopense, e foi uma pessoa de extrema importância para a educaçâo de Sinop, tanto no ensino básico quanto no ensino superior. Portanto, enxergamos a importância de valorizar as pessoas que contribuem para o desenvolvimento cultural e educacional da regiăo. 


\section{REFERÊNCIAS}

BAMPI, A. C. Aumeri Carlos Bampi: depoimento [maio 2018]. Entrevistadores: Anna C. de O. Carling. Sinop: UNEMAT, 2018. Arquivo em mp3 contendo 3,61MB. Entrevista concedida ao Trabalho de Conclusăo de Curso sobre Adelia Stedile de Matos.

BARONAS, R. L. Michel Pêcheux: um pensamento sob o signo da inquietude. In:BARONAS, R. L.; KOMESU, F. (Org.). Campinas: Mercado de Letras, 2008.

BEAUVOIR, S. de. O segundo sexo: fatos e mitos. 4. ed. Sáo Paulo: Difusăo Europeia do Livro, 1970.

BRANDÂO, H. H. N. Introduçâo à análise do discurso. 3. ed. Campinas: Editora da Unicamp, 2012.

CANDIDO, A. O estudo analítico do poema. 5. ed. Săo Paulo: Associaçăo Editorial Humanitas, 2006.

INDURSKY, F. O sujeito e as feridas narcísicas dos linguistas. Gragoatá, Niterói. n. 5, p. 111-120, 2. sem. 1998.

FERNANDES, C. A. Análise do Discurso: reflexōes introdutórias. Săo Carlos: Editora Claraluz, 2008.

MASSMANN, D.; BRASIL, P. Mulher e vulnerabilidade no direito brasileiro: uma questăo de sentidos. In: BERTOLIN, P. T. M.; ANDRADE, D. A. de; MACHADO, M. S. Mulher, Sociedade e Vulnerabilidade. Erechim: Editora Deviant, 2017.

MATOS, A. S. de. Adelia Stedile de Matos: depoimento. [mar. 2018]. Entrevistadores: Anna C. de O. Carling. Sinop, 2018a. Arquivo em mp3 contendo 12,8MB. Entrevista concedida ao Trabalho de Conclusăo de Curso sobre Adelia Stedile de Matos.

MATOS, A. S. de. Adelia Stedile de Matos: depoimento [abr. 2018]. Entrevistadores: Anna C. de O. Carling. Sinop, 2018b. Arquivo em mp3 contendo 16,25MB. Entrevista concedida ao Trabalho de Conclusăo de Curso sobre Adelia Stedile de Matos.

MATOS, A. S. de. Adelia Stedile de Matos: depoimento [jun. 2018]. Entrevistadores: Anna C. de O. Carling. Sinop, 2018c. Arquivo em mp3 contendo 11,50MB. Entrevista concedida ao Trabalho de Conclusăo de Curso sobre Adelia Stedile de Matos.

MATOS, A. S. de. Sobre mulheres e vidas. Sinop: Ideall Editoras, 2014.

MUSSALIM, F. Análise do Discurso. In: MUSSALIM, F.; CHRISTINA, A. (Org.). Introduçâo à linguística: domínios e fronteiras. Sáo Paulo: Cortez, 2006. 
OLIVEIRA, M. de F. C. B. de. A mídia e as mulheres: feminismos, representaçăo e discurso. 2005. 135 f. Dissertaçăo (Mestrado em Estudos Linguísticos e Literários em Inglês) Universidade de Săo Paulo, Săo Paulo, 2005.

OLIVEIRA, L. B. de; SOUZA, S. T. de. A alfabetizaçâo no Mobral, métodos e materiais didáticos (Uberlândia/MG, 1970-1985). Revista Acolhendo a alfabetizaçâo nos países de língua portuguesa, Sáo Paulo, v. 1, n. 13, p. 11-37, set. 2012.

ORLANDI, E. P. Análise de Discurso. In:___ _ ; Lagazzi-Rodrigues, S. Introduçāo às Ciências da Linguagem: discurso e textualidade. 3. ed. Campinas: Pontes, 2015a.

ORLANDI, E. P. Análise de Discurso e Interpretaçăo. In: ORLANDI, E. P. Discurso e texto: Formulaçăo e Circulaçăo dos Sentidos. Campinas: Pontes, 2001a.

ORLANDI, E. P. Análise de Discurso: princípios e procedimentos. 12. ed. Campinas: Pontes, 2015b.

ORLANDI, E. P. A sociolinguística, a teoria da enunciaçấo e a análise do discurso (convençăo e linguagem). In: ORLANDI, E. P. A linguagem e seu funcionamento: as formas do discurso. Sáo Paulo: Editora brasiliense, 1983.

ORLANDI, E. P. Interpretaçâo: autoria, leitura e efeitos do trabalho simbólico. 4. ed. Campinas: Pontes, 2004.

ORLANDI, E. P. Maio de 1968: Os silêncios da memória. In: ACHARD, P., et al. Papel da memória. Campinas: Pontes, 1999.

ORLANDI, E. P. O estatuto do texto na história da reflexăo sobre a Linguagem. In: ORLANDI, E. P. Discurso e texto: Formulaçấo e Circulaçāo de Sentidos. Campinas: Pontes, 2001b.

PÊCHEUX, M. Análise automática do discurso. In: GADET, F.; HAK, T. Por uma análise automática do Discurso: uma introduçáo à obra de Michel Pêcheux. 4. ed. Campinas: Editora da Unicamp, 2010b.

PÊCHEUX, M. A análise de discurso: três épocas. In: PÊCHEUX, M. Por uma análise automática do Discurso: uma introduçăo à obra de Michel Pêcheux. 4. ed. Campinas: Editora da Unicamp, 2010a.

PÊCHEUX, M. O papel da memória. In: ACHARD, P., et al. Papel da memória. Campinas: Pontes, 1999.

PÊCHEUX, M. Semântica e Discurso: uma crítica à afirmaçăo do óbvio. 2. ed. Campinas: Editora da UNICAMP, 1995. 
PICOLI, F. Fiorelo Picoli: depoimento [maio 2018]. Entrevistadores: Anna C. de O. Carling. Sinop, 2018. Arquivo em mp3 contendo 1,7MB. Entrevista concedida ao Trabalho de Conclusăo de Curso sobre Adelia Stedile de Matos.

SANTOS, J. C. dos. Josivaldo Constantino dos Santos: depoimento [jun. 2018]. Entrevistadores: Anna C. de O. Carling. Sinop, 2018. Arquivo em mp3 contendo 2,93MB. Entrevista concedida ao Trabalho de Conclusăo de Curso sobre Adelia Stedile de Matos.

TELLES, N. Escritoras, escritas, escrituras. In: PRIORE, M. D.; BASSANEZI, C. (Org.). História das mulheres no Brasil. 7. ed. Săo Paulo: Contexto, 2004.

TODA MATÉRIA. Ditadura Militar no Brasil (1964-1985). Disponível em: https://www. todamateria.com.br/ditadura-militar-no-brasil/ Acesso em: 18 jun. 2018.

TOMÉ, C. L. Sentidos sobre ser professor: a escola do professor-pioneiro em Cláudia-MT. Educaçâo (Porto Alegre, impresso), v. 37, n. 3, p. 359-368, set.-dez. 2014. 